\title{
Studi Pola Operasi Normal Waduk Mamak di Kabupaten Sumbawa Provinsi Nusa Tenggara Barat
}

\author{
Noval Irfan Kurnianto ${ }^{1 *}$, Sri Wahyuni ${ }^{1}$, Moh. Sholichin ${ }^{1}$ \\ ${ }^{1}$ Jurusan Teknik Pengairan, Fakultas Teknik, Universitas Brawijaya, \\ Jalan MT. Haryono No. 167, Malang, 65145, INDONESIA
}

*Korespondensi Email: novalirfank@gmail.com

\begin{abstract}
The reservoir operation of Mamak reservoir in Sumbawa Regency Province of West Nusa Tenggara with trial and error method and it's also not equipped with Rule Curve for Reservoir Operation so It's faced with limited water availability in water releasing for dry season.

The purpose of this study was to analyze about potential inflow and the irrigation water requirement based on planting pattern scenario. From the analysis that has been done is expected to provide an overview about the rule curve of normal operation. By $\pm 81,87$ million $\mathrm{m}^{3}$ of potential inflow in wet season and $\pm 41,14$ million $\mathrm{m}^{3}$ in dry season, the lowest irrigation water requirement was found on MT - I December-1, in wet season need to apply $\mathrm{K}$ factor $=0,70$ for MT-I and K factor $=0,60$ for MT-II to reduce that number of irrigation water requirement by $\pm 38,73$ million $\mathrm{m}^{3}$. In analyzing irrigation water requirement, It also planned with three period of planting pattern scenario so the amount of irrigation water requirement equals to 61,23 million $\mathrm{m}^{3}$ in wet season, and in dry season need to apply $\mathrm{K}$ factor $=0,70$ for MT-I and $\mathrm{K}$ factor $=0,60$ for MT-II. Operator can set water level on normal operation area based on the rule curve of normal operation.
\end{abstract}

Keywords: irrigation water requirement, $\mathrm{K}$ factor, reservoir operation, and rule curve of operation,

\begin{abstract}
Abstrak: Kondisi pengelolaan waduk Mamak di Kabupaten Sumbawa Provinsi Nusa Tenggara Barat ini masih dilakukan secara coba-coba dan belum dilengkapi dengan kurva pola operasi normal waduk sehingga seringkali dihadapkan pada kesulitan mengatur pengeluaran air dari waduk khususnya pada tahun kering yang jumlah inflownya relatif kecil dibandingkan kebutuhan air yang ada. Maksud studi ini adalah untuk mengkaji potensi air dan rencana kebutuhan air sesuai dengan pola tanam serta areal irigasi yang ada sehingga dapat disusun Kurva Pola Operasi Normal Waduk yang menjadi acuan operasional. Dengan potensi inflow sebesar $\pm 81,87$ juta $\mathrm{m}^{3}$ pada kondisi tahun basah dan $\pm 41,14$ juta $\mathrm{m}^{3}$ untuk tahun kering, kebutuhan air akan terpenuhi secara
\end{abstract}


optimal jika awal MT-I berada pada bulan Desember-1, namun untuk kondisi pada tahun kering perlu memberlakukan Faktor K 0,7 pada MT-I dan Faktor K 0,6 pada

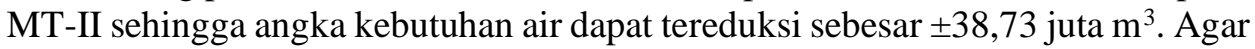
pemanfaatan waduk lebih optimal, pada studi ini dilakukan analisa rencana kebutuhan air dengan pola tanam 3 musim sehingga dengan angka kebutuhan air yang sedikit lebih besar yaitu 61,23 juta $\mathrm{m}^{3}$ masih dapat terpenuhi pada tahun basah, dan untuk tahun kering dapat memberlakukan factor $\mathrm{K}$ sebesar 0,70 untuk MT-I dan 0,60 untuk MT-II. Dengan adanya kurva pola operasi waduk maka petugas operasional hanya perlu mengatur posisi elevasi muka air berada di "daerah operasi normal".

Kata Kunci: faktor K, kebutuhan air irigasi, kurva pola operasi, dan operasi waduk.

\section{Pendahuluan}

Provinsi Nusa Tenggara Barat (NTB) telah memiliki banyak bendungan/waduk sebagai bangunan utama untuk jaringan irigasi, namun sebagian besar belum dilakukan pengelolaan secara optimal sehingga hal ini juga berdampak langsung pada belum optimalnya hasil produksi pertanian. Pengelolaan waduk di provinsi ini masih dilakukan secara coba-coba dan/atau belum dilengkapi dengan kurva pola operasi normal waduk sehingga seringkali dihadapkan pada kesulitan mengatur pengeluaran air dari waduk khususnya pada tahun kering yang jumlah inflownya relatif kecil dibandingkan kebutuhan air yang ada.

Diperlukan sebuah petunjuk berupa kurva pola operasi normal waduk yang dibuat berdasarkan analisis keseimbangan air, berisikan informasi batas atas dan batas bawah muka air waduk pada periode setengah bulanan sehingga petugas operasional bisa memperkirakan pengeluaran air secara baik dan aman [5]. Sehingga pada prinsipnya, studi ini dimaksudkan untuk mengkaji potensi air dan rencana kebutuhan air sesuai dengan pola tanam serta areal irigasi yang ada sehingga dapat disusun Kurva Pola Operasi Normal Waduk yang menjadi acuan operasional.

Berdasarkan data tanam 5 tahun terakhir, capaian intensitas tanam dari Waduk Mamak hanya 2 musim pertahun, yaitu: Padi - Padi/Palawija - Bero [2]. Permasalahan yang cukup mendesak pada saat ini adalah belum adanya kurva pola operasi normal waduk yang bisa memberikan acuan operasional air waduk, baik kondisi tahun basah maupun tahun kering sehingga operasional yang selama ini dilakukan bersifat coba-coba. Seharusnya, semua waduk dalam operasionalnya sudah memiliki kurva pola operasi normal waduk yang diwujudkan dalam bentuk Rule Curves Zona Operasi, yang dibatasi oleh lengkung batas operasi normal atas dan lengkung batas operasi normal bawah [6]. Lengkung ini dibuat di buat dengan mempertimbangkan:

a. Kondisi aliran sungai pada musim hujan untuk membuat grafik batas atas dan musim kemarau untuk membuat grafik batas bawah. 
b. Kebutuhan air yang harus terpenuhi sesuai rencana pokok penyediaan air. Untuk irigasi, biasanya ada keputusan dari gubernur/pemda tentang rencana tanam musim tanam setiap tahun.

\section{Bahan dan Metode}

\subsection{Bahan}

Studi ini berada pada Waduk Mamak di Kecamatan Lape Kabupaten Sumbawa Provinsi Nusa Tenggara Barat.

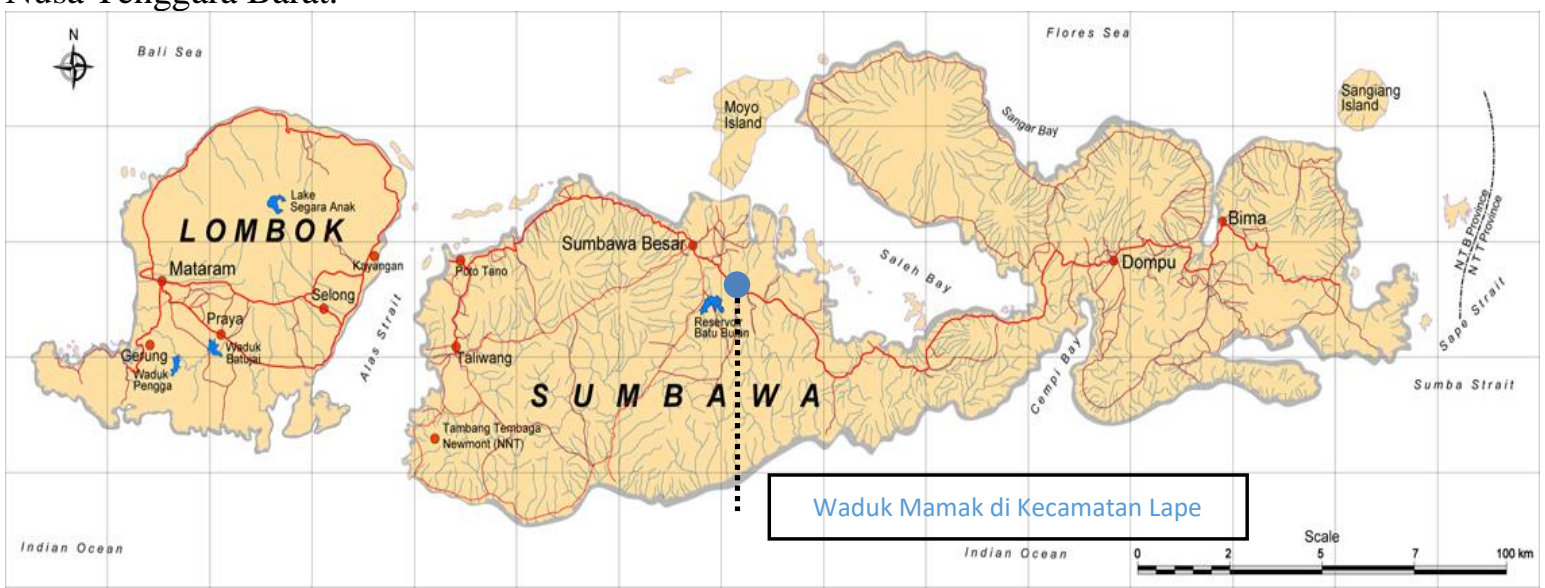

\section{Gambar 1. Peta Lokasi Waduk Mamak}

Sumber: Hasil Penggambaran

Data-data yang diperlukan untuk analisis dalam studi ini dalah data sekunder yang dikumpulkan dari instansi terkait, yaitu:

- Data Curah Hujan dan Data Iklim; data ini diperoleh dari Kantor Balai Informasi Infrastrukrur Wilayah (BIIW) Dinas Pekerjaan Umum Provinsi NTB di Mataram. Data yang didapat meliputi data curah hujan Stasiun Pungkit Atas dan Rea Atas serta data Klimatologi Plampang.

- Data Teknis Waduk; data teknis waduk diperlukan untuk bahan analisis keseimbangan air diperoleh dari Kantor Balai Wilayah Sungai Nusa Tenggara I (BWS NT I).

- Data Operasional Waduk; data operasional waduk diperlukan untuk analisis ketersediaan air maupun evaluasi operasional waduk. Data ini diperoleh dari kantor BWS NT I bagian monitoring bendungan.

- Data Pola Tanam; data realisasi tanam diperlukan untuk menyusun rencana pola tanam dan kebutuhan air. Data ini diperoleh dari Dinas PU Kabupaten Sumbawa. 


\subsection{Metode}

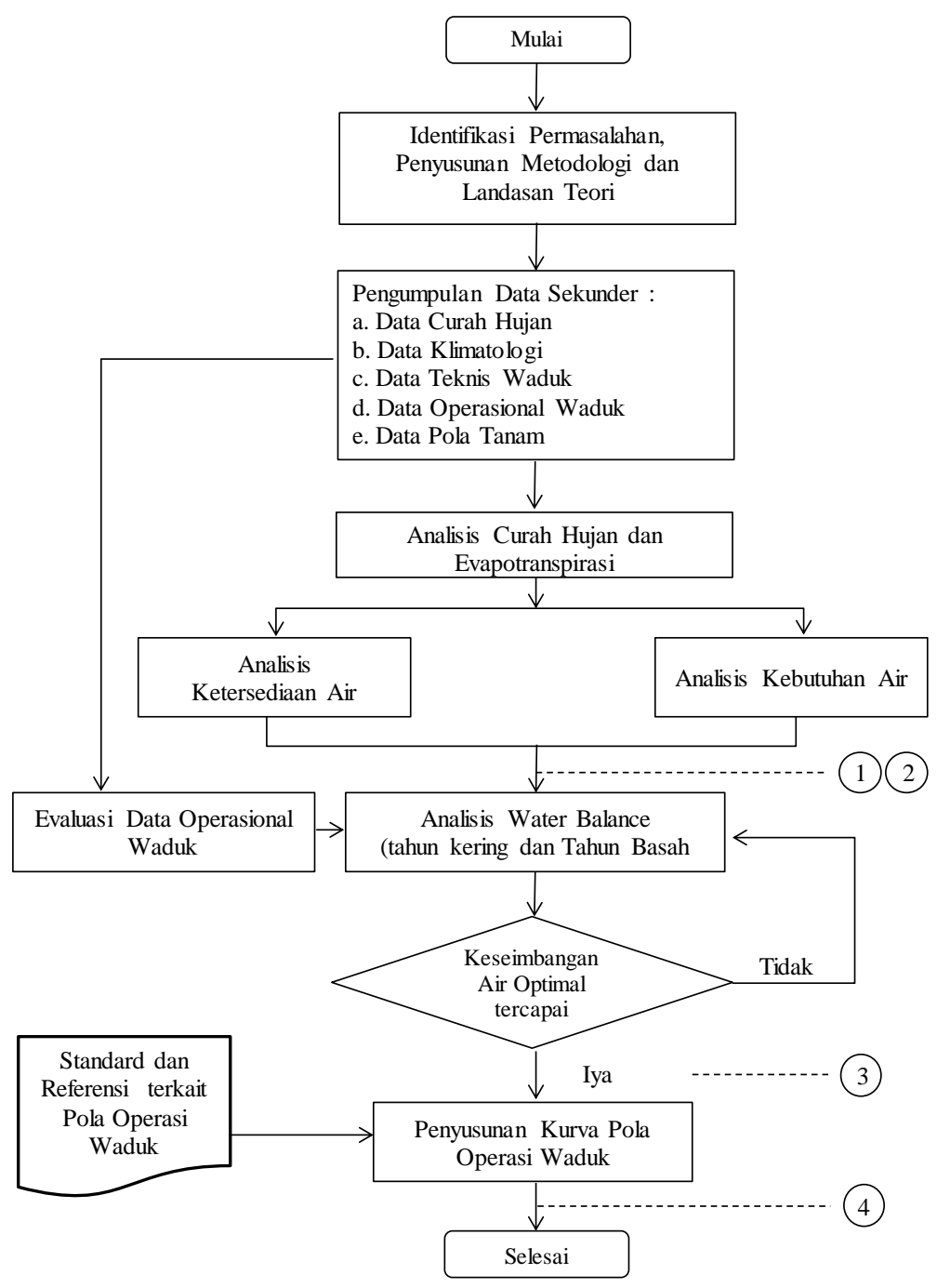

Gambar 2. Bagan Alir Pengerjaan Studi

Sumber: Hasil Penggambaran

\subsection{Persamaan}

\section{A. Curah Hujan Rerata Daerah}

Cara ini adalah dengan memasukkan faktor pengaruh daerah yang mewakili oleh stasiun hujan yang disebut faktor pembobotan atau koefisien Thiessen [1]

$$
P=\frac{\mathrm{A}_{1} \mathrm{P}_{1}+\mathrm{A}_{2} \mathrm{P}_{2}+\ldots+\mathrm{A}_{\mathrm{n}} \mathrm{P}_{\mathrm{n}}}{\mathrm{A}} \quad \text { Pers. } 1
$$


Keterangan :

$\mathrm{P} 1, \mathrm{P} 1, \mathrm{Pn}=$ kedalaman hujan di stasiun $1,2, \mathrm{n}$

$\mathrm{A} 1 \mathrm{~A} 2 \mathrm{An} \quad=$ luas daerah yang diwakili stasiun $1,2, \mathrm{n}$

$\mathrm{P} \quad=$ hujan rata-rata DAS

A $\quad=$ luas areal

\section{B. Curah Hujan Andalan}

Curah hujan andalan untuk tanaman padi ditetapkan sebesar $80 \%$ sedangkan untuk tanaman palawija sebesar $50 \%$. Langkah-langkah dalam penentuan curah hujan andalan yaitu $:[4]$

- Urutkan data curah hujan rerata daerah bulanan dari kecil ke besar.

- Tentukan curah hujan andalan dengan rumus:

$$
\begin{array}{ll}
R_{80}=\frac{n}{5}+1 & \text { Pers. 2 } \\
R_{50}=\frac{n}{2}+1 & \text { Pers. 3 }
\end{array}
$$

dengan:

$\mathrm{R}_{80} \quad=$ curah hujan andalan $80 \%$

$\mathrm{R}_{50} \quad=$ curah hujan andalan $50 \%$

$\mathrm{n} \quad=$ jumla data

\section{Curah Hujan Effektif}

Persamaan curah hujan efektifnya dapat dihitung dengan rumus: [4] Padi

$$
\mathrm{R}_{\mathrm{eff}}=0,70\left(\frac{R_{80}}{15}\right) \quad \text { Pers. } 4
$$

dengan:

$\mathrm{R}_{\mathrm{eff}} \quad=$ Curah Hujan Efektif $(\mathrm{mm})$

$\mathrm{R}=$ Curah hujan andalan $80 \%(\mathrm{~mm})$

\section{Palawija}

Untuk curah hujan efektif palawija di hitung berdasarkan ketentuan pada Kriteria Perencanaan (KP) 01.[3]

\section{Analisis Ketersediaan Air}

Dalam studi ini analisi ketersediaan air dihitung menggunakan debit andalan metode basic year yang akan menghasilkan potensi inflow. [2]

1. Debit andalan $80 \%\left(\mathrm{Q}_{80}\right)$ biasa digunakan untuk menggambarkan debit tahun kering.[2]

2. Debit andalan $20 \%\left(\mathrm{Q}_{20}\right)$ biasa digunakan untuk menggambarkan debit tahun basah.[10]

\section{E. Analisis Kebutuhan Air}

Kebutuhan air irigasi dihitung dengan persamaan : [4]

$$
\text { Kai }=\frac{(\mathrm{Etc}+\mathrm{I}+\mathrm{Wlr}+\mathrm{P}-\mathrm{Re})}{\mathrm{Ei}} A \quad \text { Pers. } 5
$$




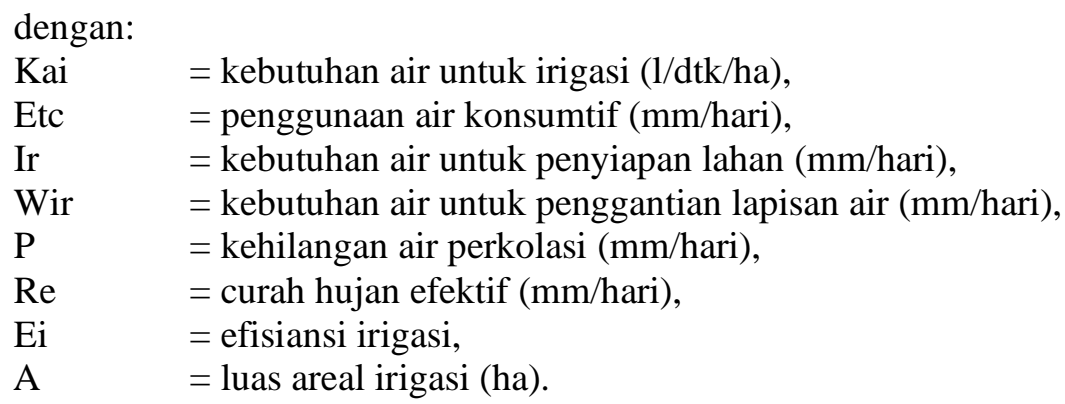

\section{F. Analisis Keseimbangan Air}

Detail persamaam simulasi dikembangkan sebagai berikut: [5].

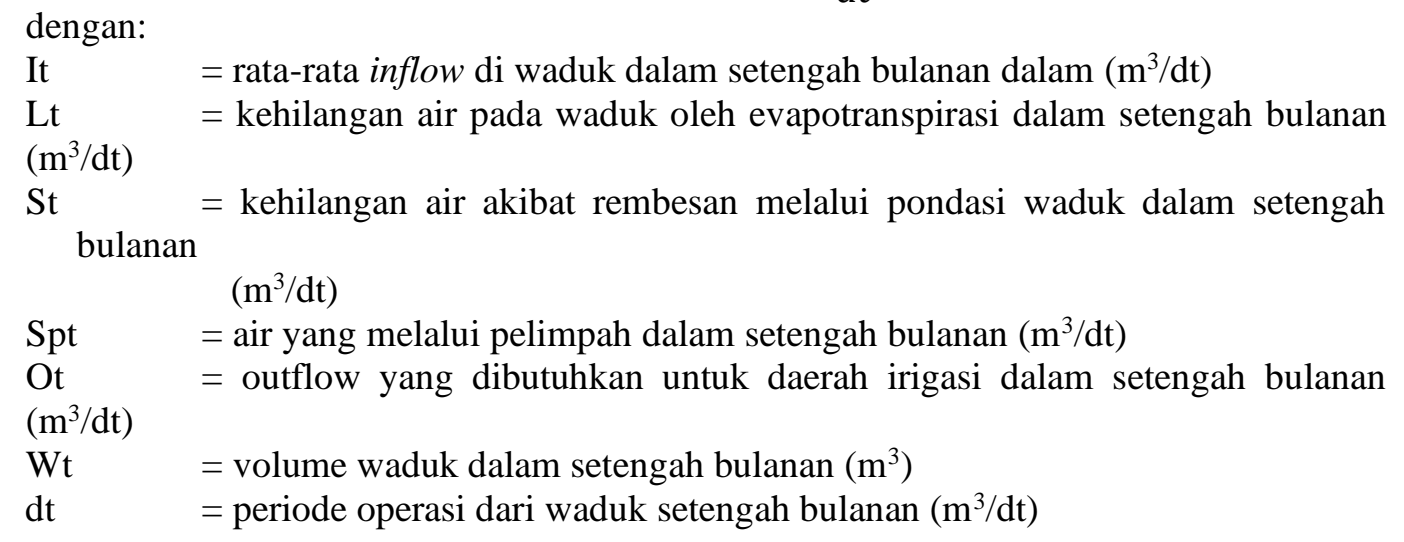

$$
\mathrm{I}_{\mathrm{t}}-\mathrm{L}_{\mathrm{t}}-\mathrm{S}_{\mathrm{t}}-\mathrm{SP}_{\mathrm{t}}-\mathrm{O}_{\mathrm{t}}=\frac{\left(\mathrm{W}_{\mathrm{t}}-\mathrm{W}_{\mathrm{t}-1}\right)}{\mathrm{dt}} \quad \text { Pers. } 6
$$

\section{G. Faktor $\mathbf{K}$}

Apabila dari hasil pencatatan debit di sungai (inflow) terjadi kekurangan air (pada tanggal tertentu) maka pembagian dan pemberian air irigasi perlu dikoreksi dengan menggunakan perhitungan faktor K [3].

dengan :

$$
\mathrm{K}=\frac{Q_{\text {tersedia }}}{Q_{\text {butuh }}} \quad \text { Pers. } 7
$$

Q

Qbutuh = debit yang dibutuhkan untuk air irigasi $\left(\mathrm{m}^{3} / \mathrm{dt}\right)$

\section{Hasil dan Pembahasan}

\subsection{Analisis Curah Rerata Daerah}

Perhitungan dilakukan dengan metode metode polygon thiessen pada Data Curah Hujan Stasiun Pungkit Atas dengan pengaruh koefisien thiessen 1,00. Analisa untuk tahun 1995-2016 adalah sebagai berikut [9]: Tabel 1. 


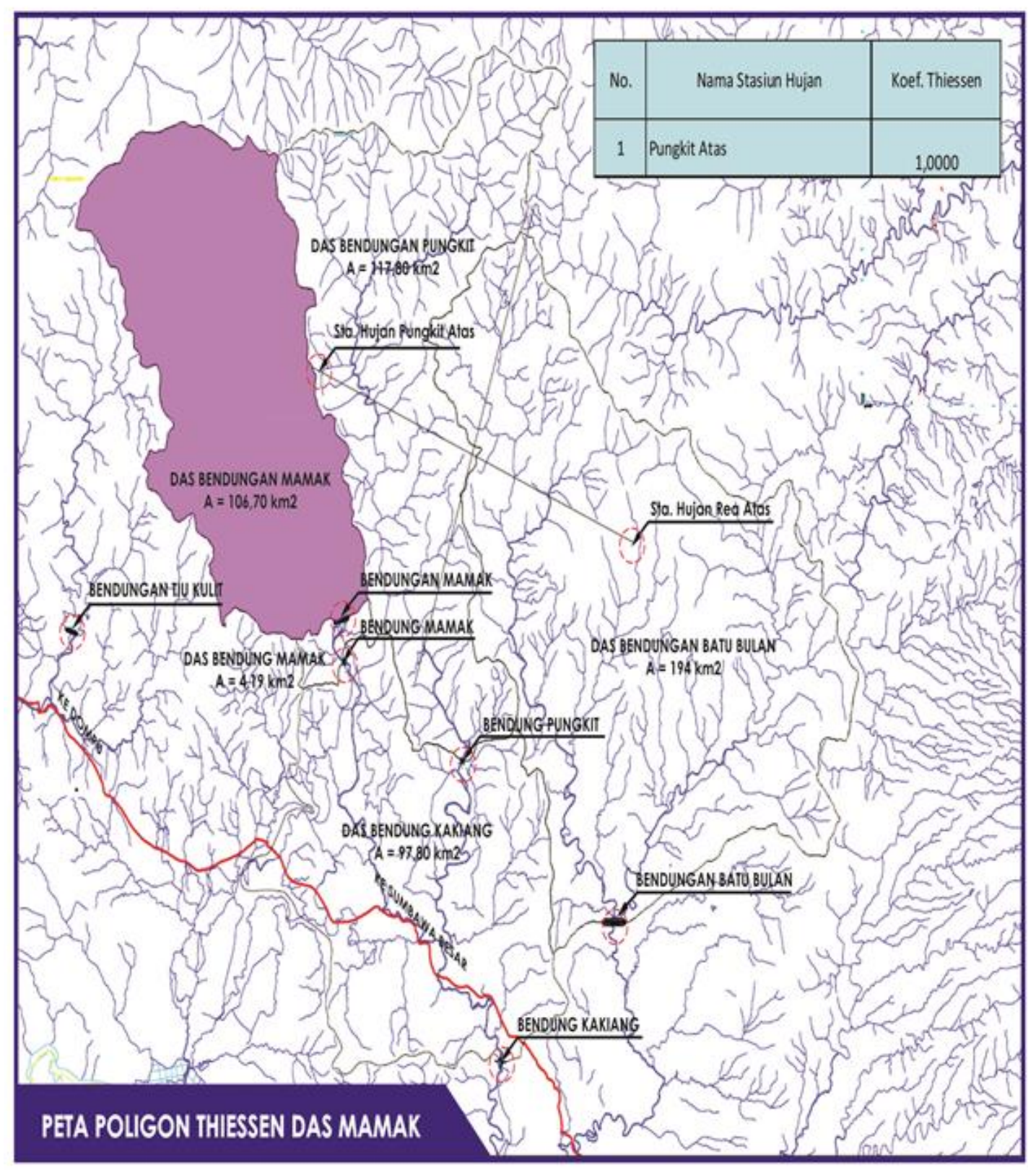

Gambar 3. DAS Mamak dan Stasiun Hujan yang berpengaruh

Sumber: Hasil Penggambaran 
Tabel 1. Perhitungan Curah Hujan Rerata Daerah

\begin{tabular}{|c|c|c|c|c|c|c|c|c|c|c|c|c|c|c|c|c|c|c|c|c|c|c|c|c|c|}
\hline \multirow[t]{2}{*}{ Tahun } & \multicolumn{2}{|l|}{ Januari } & \multicolumn{2}{|c|}{ Februari } & \multicolumn{2}{|l|}{ Maret } & \multicolumn{2}{|l|}{ April } & \multicolumn{2}{|l|}{ Mei } & \multicolumn{2}{|l|}{ Juni } & \multicolumn{2}{|l|}{ Juli } & \multicolumn{2}{|l|}{ Agustus } & \multicolumn{2}{|c|}{ September } & \multicolumn{2}{|l|}{ Oktober } & \multicolumn{2}{|c|}{ November } & \multicolumn{2}{|c|}{ Desember } & \multirow{2}{*}{ Jumlah } \\
\hline & I & II & I & II & I & II & I & II & II & I & II & I & II & I & II & & I & & I & & I & II & I & II & \\
\hline 1995 & 177,3 & 88,5 & 95,8 & 55,4 & 131,6 & 49,3 & 42,3 & 0,0 & 0,0 & 0,0 & 7,2 & 0,0 & 0,0 & 0,0 & 0,0 & 0,0 & 0,0 & 0,0 & 0,0 & 20,0 & 173,0 & 175,0 & 154,0 & 86,6 & 1256,0 \\
\hline 1996 & 164,7 & 230,2 & 206,5 & 317,5 & 191,3 & 55,3 & 157,5 & 10,9 & 0,0 & 0,0 & 0,0 & 0,0 & 0,0 & 0,0 & 0,0 & 0,0 & 0,0 & 0,0 & 0,0 & 16,7 & 20,7 & 164,4 & 168,2 & 55,2 & 1759,1 \\
\hline 1997 & 110,7 & 209,7 & 259,7 & 172,3 & 69,6 & 27,1 & 91,6 & 21,5 & 0,0 & 55,2 & 0,0 & 0,0 & 0,0 & 0,0 & 0,0 & 0,0 & 0,0 & 0,0 & 0,0 & 0,0 & 0,0 & 134,5 & 146,0 & 124,9 & 1422,7 \\
\hline 1998 & 114,8 & 94,7 & 133,8 & 65,2 & 188,4 & 140,6 & 87,6 & 141,5 & 0,0 & 34,1 & 38,6 & 55,8 & 20,5 & 69,8 & 0,0 & 0,0 & 0,0 & 48,3 & 40,1 & 84,1 & 113,0 & 144,3 & 115,3 & 283,3 & 2013,8 \\
\hline 1999 & 97,2 & 51,1 & 213,8 & 264,7 & 150,4 & 321,2 & 178,7 & 54,5 & 0,0 & 0,0 & 0,0 & 0,0 & 6,3 & 0,0 & 0,0 & 0,0 & 0,0 & 0,0 & 28,2 & 25,8 & 83,8 & 255,9 & 131,1 & 83,1 & 1945,8 \\
\hline 2000 & 77,9 & 69,4 & 58,2 & 87,0 & 83,6 & 152,8 & 118,1 & 152,7 & 24,1 & 42,9 & 0,0 & 0,0 & 0,0 & 0,0 & 0,0 & 0,0 & 0,0 & 0,0 & 47,2 & 64,2 & 103,5 & 96,2 & 128,4 & 96,2 & 1402,4 \\
\hline 2001 & 146,0 & 108,1 & 237,0 & 53,6 & 132,0 & 150,9 & 77,9 & 6,8 & 0,0 & 24,7 & 20,7 & 3,7 & 0,0 & 0,0 & 0,0 & 0,0 & 0,0 & 0,0 & 12,0 & 64,2 & 48,6 & 92,9 & 112,6 & 91,4 & 1383,1 \\
\hline 2002 & 103,1 & 279,1 & 88,3 & 70,8 & 81,6 & 123,8 & 200,4 & 0,0 & 0,0 & 0,0 & 0,0 & 0,0 & 0,0 & 0,0 & 0,0 & 0,0 & 0,0 & 0,0 & 0,0 & 0,0 & 53,4 & 197,4 & 187,3 & 167,4 & 1552,6 \\
\hline 2003 & 210,1 & 261,0 & 220,1 & 247,3 & 152,5 & 22,6 & 71,4 & 0,0 & 0,0 & 0,0 & 0,0 & 0,0 & 0,0 & 0,0 & 0,0 & 0,0 & 2,1 & 37,7 & 10,0 & 0,0 & 8,4 & 201,3 & 182,8 & 144,2 & 1771,5 \\
\hline 2004 & 146,7 & 149,0 & 102,4 & 163,7 & 61,0 & 102,2 & 172,9 & 0,0 & 0,0 & 47,8 & 0,0 & 0,0 & 0,0 & 0,0 & 0,0 & 0,0 & 0,0 & 0,0 & 0,0 & 0,0 & 3,0 & 75,9 & 150,2 & 184,7 & 1359,4 \\
\hline 2005 & 100,7 & 137,6 & 200,2 & 134,8 & 161,5 & 208,9 & 209,6 & 0,0 & 0,0 & 0,0 & 0,0 & 5,0 & 8,8 & 0,0 & 8,3 & 5,7 & 0,0 & 0,0 & 23,5 & 82,8 & 23,5 & 106,0 & 112,8 & 130,2 & 1659,9 \\
\hline 2006 & 263,9 & 297,7 & 124,7 & 244,8 & 114,1 & 328,7 & 48,2 & 42,0 & 91,8 & 28,4 & 0,0 & 11,0 & 0,0 & 0,0 & 0,0 & 0,0 & 0,0 & 7,3 & 0,0 & 0,0 & 21,7 & 240,4 & 125,5 & 226,6 & 2216,7 \\
\hline 2007 & 69,2 & 177,8 & 190,0 & 75,2 & 148,6 & 146,8 & 84,5 & 56,9 & 0,0 & 24,7 & 0,0 & 28,8 & 0,0 & 0,0 & 0,0 & 0,0 & 0,0 & 0,0 & 0,0 & 13,2 & 34,5 & 66,0 & 161,7 & 144,4 & 1422,3 \\
\hline 2008 & 97,7 & 112,6 & 121,7 & 77,6 & 100,2 & 181,0 & 99,8 & 2,2 & 0,0 & 0,0 & 0,0 & 0,0 & 0,0 & 0,0 & 1,5 & 0,0 & 0,0 & 23,0 & 10,0 & 46,6 & 94,8 & 204,7 & 200,7 & 186,7 & 1560,8 \\
\hline 2009 & 147,8 & 77,0 & 62,6 & 237,1 & 71,5 & 80,6 & 61,4 & 0,0 & 69,7 & 40,1 & 0,0 & 0,0 & 0,3 & 0,0 & 0,0 & 0,0 & 0,0 & 14,0 & 7,0 & 3,1 & 40,6 & 57,5 & 171,6 & 88,8 & 1230,7 \\
\hline 2010 & 215,5 & 50,7 & 166,1 & 64,4 & 130,5 & 67,3 & 74,7 & 50,7 & 20,6 & 175,1 & 1,8 & 54,7 & 30,4 & 31,0 & 0,8 & 0,0 & 0,7 & 20,0 & 0,0 & 214,8 & 105,1 & 62,7 & 98,3 & 79,6 & 1715,6 \\
\hline 2011 & 177,6 & 50,9 & 54,8 & 175,2 & 74,2 & 52,2 & 40,5 & 42,2 & 52,3 & 4,5 & 36,4 & 8,2 & 0,0 & 12,0 & 8,7 & 6,6 & 0,0 & 27,0 & 0,9 & 0,0 & 7,6 & 75,5 & 103,5 & 76,7 & 1087,5 \\
\hline 2012 & 72,2 & 120,0 & 119,2 & 54,0 & 122,1 & 129,0 & 51,3 & 45,2 & 17,8 & 7,3 & 0,0 & 0,0 & 0,0 & 14,5 & 0,0 & 0,0 & 0,0 & 0,0 & 0,0 & 0,0 & 78,6 & 151,1 & 100,2 & 315,1 & 1397,6 \\
\hline 2013 & 275,6 & 154,0 & 102,6 & 106,5 & 177,8 & 37,0 & 125,0 & 0,0 & 42,0 & 80,0 & 0,0 & 59,3 & 0,0 & 0,0 & 0,0 & 0,0 & 0,0 & 0,0 & 0,0 & 0,0 & 50,0 & 112,0 & 152,0 & 174,6 & 1648,4 \\
\hline 2014 & 162,7 & 204,9 & 80,1 & 65,7 & 182,3 & 29,4 & 124,2 & 130,1 & 17,0 & 0,0 & 0,0 & 0,0 & 30,0 & 0,0 & 0,0 & 0,0 & 0,0 & 0,0 & 0,0 & 0,0 & 147,5 & 181,2 & 168,9 & 112,2 & 1636,2 \\
\hline 2015 & 8,3 & 147,8 & 63,7 & 79,2 & 124,2 & 113,1 & 21,1 & 71,9 & 0,0 & 0,0 & 0,0 & 0,0 & 0,0 & 0,0 & 0,0 & 0,0 & 0,0 & 0,0 & 0,0 & 0,0 & 6,5 & 18,8 & 200,2 & 49,6 & 904,4 \\
\hline 2016 & 124,3 & 199,4 & 163,3 & 91,3 & 71,3 & 48,8 & 304,1 & 39,8 & 1,0 & 27,1 & 19,2 & 31,6 & 19,9 & 18,3 & 30,6 & 8,1 & 74,5 & 60,8 & 22,0 & 133,5 & 8,4 & 57,2 & 102,5 & 61,3 & 1718,3 \\
\hline Rerata & 139,3 & 148,7 & 139,3 & 132,0 & 123,6 & 116,8 & 111,0 & 39,5 & 15,3 & 26,9 & 5,6 & 11,7 & 5,3 & 6,6 & 2,3 & 0,9 & 3,5 & 10,8 & 9,1 & 35,0 & 55,7 & 130,5 & 144,3 & 134,7 & 1548,4 \\
\hline
\end{tabular}

\subsection{Analisis Curah Hujan Effektif}

Analisis ini dilakukan menggunakan data hasil perhitungan Curah Hujan andalan [4].

Tabel 3. Perhitungan Curah Hujan Effektif

\begin{tabular}{rrrrrccc}
\hline Bulan & & Padi & Palawija & Bulan & Padi & Palawija \\
\hline Januari & I & 4,18 & 0,00 & Juli & I & 0,00 & 1,67 \\
& II & 3,24 & 0,00 & \multirow{2}{*}{ Agustus } & II & 0,00 & 1,67 \\
Februari & I & 3,68 & 0,00 & & 0,00 & 1,67 \\
& II & 3,24 & 1,67 & \multirow{2}{*}{ Setember } & II & 0,00 & 1,67 \\
Maret & I & 3,41 & 1,67 & 0,00 & 0,00 \\
& II & 1,93 & 1,67 & & II & 0,00 & 0,00 \\
April & I & 2,34 & 1,67 & Oktober & I & 0,00 & 0,00 \\
& II & 0,00 & 0,00 & & II & 0,00 & 0,00 \\
Mei & I & 0,00 & 0,00 & Nopember & I & 0,38 & 0,00 \\
& II & 0,00 & 0,00 & & II & 3,02 & 0,00 \\
Juni & I & 0,00 & 0,00 & Desember & I & 5,09 & 0,00 \\
& II & 0,00 & 1,67 & & II & 3,43 & 0,00 \\
\hline
\end{tabular}

Sumber: Hasil Perhitungan

\subsection{Analisis Ketersediaan Air}

Analisis menggunakan metode Basic Year karena memenuhi syarat perhitungan dengan kondisi data lebih dari 10 tahun [10]. Perhitungan debit andalan dilakukan pada tahun 20052016, ditampilkan pada Tabel 4. 
Tabel 4. Debit Andalan DAS Mamak

\begin{tabular}{|c|c|c|c|c|c|c|c|c|c|c|c|c|c|}
\hline \multirow{2}{*}{\multicolumn{2}{|c|}{ Prob }} & \multicolumn{2}{|l|}{ Januari } & \multicolumn{2}{|c|}{ Pebruari } & \multicolumn{2}{|l|}{ Maret } & \multicolumn{2}{|l|}{ April } & \multicolumn{2}{|l|}{ Mei } & \multicolumn{2}{|l|}{ Juni } \\
\hline & & I & II & I & II & I & II & I & II & I & II & I & II \\
\hline $\mathrm{R}$ & $80 \%$ & 1,78 & 2,22 & 1,79 & 8,00 & 1,30 & 0,94 & 0,69 & 2,15 & 1,02 & 1,38 & 0,17 & 0,39 \\
\hline \multirow[t]{3}{*}{$\mathrm{R}$} & $20 \%$ & 1,73 & 2,89 & 4,45 & 4,77 & 7,33 & 6,46 & 2,61 & 2,24 & 1,31 & 0,69 & 1,35 & 0,30 \\
\hline & & Juli & & Agust & & Sep & & Okt & & Nop & & Des & \\
\hline & rob & I & II & I & II & I & II & I & II & I & II & I & II \\
\hline $\mathrm{R}$ & $80 \%$ & 0,14 & 0,30 & 1,04 & 1,64 & 0,04 & 0,31 & 0,25 & 0,31 & 1,26 & 0,71 & 0,28 & 3,60 \\
\hline $\mathrm{R}$ & $20 \%$ & 1,31 & 0,90 & 0,51 & 1,43 & 0,42 & 0,99 & 0,56 & 0,51 & 1,80 & 3,00 & 8,15 & 6,75 \\
\hline
\end{tabular}

Sumber: Hasil Perhitungan

Potensi Inflow Andalan 20\% (mewakili data kondisi tahun basah) adalah sebesar \pm 81,87 juta $\mathrm{m} 3$ per tahun, terdistribusi menurut kondisi musim tanam (MT) sebagai berikut [3] :

- $\quad$ MT I (Des I - April II) adalah 62,00 juta m3 (75,73\%)

- $\quad$ MT II (Mei I - Sep II) adalah 12,22 juta m3 (14,92\%)

- $\quad$ MT III/(Bero) adalah 7,65 juta m3 (9,35\%)

Potensi Inflow Andalan 80\% (mewakili data kondisi tahun kering) adalah sebesar $\pm 41,14$ juta $\mathrm{m}^{3}$, terdistribusi menurut kondisi musim tanam (MT) sebagai berikut :

- $\quad$ MT I (Des I - April II) adalah 29,21 juta $\mathrm{m}^{3}(71,00 \%)$

- $\quad$ MT II (Mei I - Sep II) adalah 8,61 juta $\mathrm{m}^{3}(20,94 \%)$

- $\quad$ MT III/Bero adalah 3,32 juta ${ }^{3}(8,06 \%)$

\subsection{Kebutuhan Air Irigasi}

Perhitungan kebutuhan air dilakukan untuk jenis tanaman per musim, yaitu Padi musim tanam I dan II, serta palawija musim tanam II dan III, sehingga dalam analisis keseimbangan air prosentase luas tanam padi maupun palawija dapat dilakukan secara coba-coba secara fleksibel agar didapatkan kombinasi pola dan intensitas tanam yang optimal dari segi pemanfaatan air.

Secara ringkas, hasil perhitungan kebutuhan air irigasi pada DI. Mamak dapat dilihat pada Tabel.6. Pada analisis kebutuhan air, dilakukan berbagai alternatif perhitungan dengan menggeser awal MT-I yaitu; Nopember-1, Nopember-2, Desember-1, dan Desember-2. Dari hasil analisis berikut menghasilkan kebutuhan air intake maksimum terkecil jika awal MT-I berada pada Desember-1 dengan asumsi bahwa pola tanam Gabungan adalah Padi (100\%) Padi (52\%) /Palawija (48\%) - Bero[4].

Tabel 5. Perhitungan Kebutuhan Air Des-1

\begin{tabular}{|c|c|c|c|c|c|c|c|c|c|c|c|c|c|c|}
\hline \multirow{3}{*}{$\begin{array}{c}\text { Alternatif } \\
\text { Penyiapan } \\
\text { Lahan }\end{array}$} & \multicolumn{12}{|c|}{ Bulan } & \multirow{3}{*}{$\begin{array}{c}\text { DR } \\
\text { Mak } \\
\text { lt/dt/ha }\end{array}$} & \multirow{3}{*}{$\begin{array}{l}\text { DR } \\
\text { Rerata } \\
\text { lt/dt/h }\end{array}$} \\
\hline & \multicolumn{2}{|c|}{ Jan } & \multicolumn{2}{|c|}{ Feb } & \multicolumn{2}{|c|}{ Mar } & \multicolumn{2}{|c|}{ Apr } & \multicolumn{2}{|c|}{ Mei } & \multicolumn{2}{|c|}{ Jun } & & \\
\hline & I & II & I & II & I & II & I & II & I & II & I & II & & \\
\hline \multirow{5}{*}{$\begin{array}{l}\text { Awal LP - Des } 1 \\
\text { a. Padi } \\
\text { b. Palawija } \\
\text { Pola Tanam Gabu } \\
(48 \%)\end{array}$} & & & & & & & & & & & & & \multirow{3}{*}{1,43} & \multirow{4}{*}{$\begin{array}{l}0,86 \\
0,20\end{array}$} \\
\hline & 0,94 & 1,06 & 0,74 & 0,61 & 0,50 & 0,57 & 0,17 & 0,60 & 1,16 & 1,37 & 1,43 & 1,17 & & \\
\hline & & & & & & & & 0,07 & 0,17 & 0,27 & 0,33 & 0,18 & & \\
\hline & gan : & & $\%)$ - & & ) / P & wija & & & & & & & & \\
\hline & 0,94 & 1,06 & 0,74 & 0,61 & 0,50 & 0,57 & 0,17 & 0,64 & 0,68 & 0,84 & 0,90 & 0,69 & 0,00 & 0,70 \\
\hline
\end{tabular}




\begin{tabular}{|c|c|c|c|c|c|c|c|c|c|c|c|c|c|c|}
\hline \multirow{3}{*}{$\begin{array}{c}\text { Alternatif } \\
\text { Alternatif } \\
\text { Penyiapan } \\
\text { Lahan }\end{array}$} & \multicolumn{12}{|c|}{ Bulan } & \multirow[t]{3}{*}{ DR } & \multirow[t]{3}{*}{ DR } \\
\hline & \multicolumn{2}{|c|}{ Jul } & \multicolumn{2}{|c|}{ Agust } & \multicolumn{2}{|c|}{ Sep } & \multicolumn{2}{|c|}{ Okt } & \multicolumn{2}{|c|}{ Nop } & \multicolumn{2}{|c|}{ Des } & & \\
\hline & I & II & I & II & I & II & I & II & I & II & I & II & & \\
\hline \multicolumn{15}{|l|}{ Awal LP - Des 1} \\
\hline a. Padi & 1,10 & 1,07 & 0,89 & 0,58 & 0,24 & 0,12 & & & & & 0,21 & 0,78 & 1,43 & 0,86 \\
\hline b. Palawija & 0,23 & 0,10 & 0,01 & 0,00 & 0,19 & 0,34 & 0,55 & 0,57 & 0,39 & 0,11 & 0,00 & & & 0,20 \\
\hline \multicolumn{15}{|c|}{$\begin{array}{l}\text { Pola Tanam Gabungan : Padi (100\%) - Padi (52\%) / Palawija } \\
(48 \%)\end{array}$} \\
\hline & 0,68 & 0,61 & 0,47 & 0,58 & 0,24 & 0,12 & & & & & 0,21 & 0,78 & 0,00 & 0,70 \\
\hline
\end{tabular}

Sumber: Hasil Perhitungan

\subsection{Penyusunan Kurva Pola Operasi}

Data teknis kapasitas tampungan total Waduk Mamak adalah 32,5 juta $\mathrm{m}^{3}$, dengan volume tampungan sedimen sebesar 2,5 juta $\mathrm{m}^{3}$ sehingga tampungan efektif waduk adalah 30 juta $\mathrm{m}^{3}$.

\section{Kurva Batas Bawah}

Kurva batas bawah dibuat berdasarkan hasil analisis keseimbangan air dengan debit andalan 80\% (mewakili kondisi tahun kering) [6]. Tampungan awal dalam analisis keseimbangan air ditetapkan sebesar 3,75 juta $\mathrm{m}^{3}$ dengan pertimbangan bahwa pada kondisi ini didalam waduk masih terdapat tampungan efektif sebesar 1,25 juta $\mathrm{m}^{3}$ yang dapat digunakan sebagai cadangan air untuk operasional penyiapan lahan selama 1 periode ( 2 mingguan) bilamana terjadi kelambatan musim hujan. Dalam analisis keseimbangan air, diupayakan tampungan waduk pada akhir operasional setara dengan tampungan awal operasi $\left(3.750 .000 \mathrm{~m}^{3}\right)$.

Dalam penentuan kurva batas bawah, dilakukan penilaian hasil analisis keseimbangan air, meliputi aspek: keberhasilan operasional, sisa tampungan pada akhir operasi, limpasan di spillway, defisit air waduk serta keberhasilan operasional pada daerah irigasi terkait [6].

Tabel 6. Hasil Penilaian Kurva Batas Bawah

\begin{tabular}{|c|c|c|c|c|c|c|c|c|c|c|}
\hline \multirow{2}{*}{ No. } & \multirow[t]{2}{*}{ Poin Penilaian } & \multirow{2}{*}{$\begin{array}{c}\text { Bobot } \\
\text { Nilai }\end{array}$} & \multicolumn{4}{|c|}{ Kondisi Hasil Analisis } & \multicolumn{4}{|c|}{ Nilai } \\
\hline & & & Nov. 1 & Nov.2 & Des. 1 & Des.2 & Nov. 1 & Nov.2 & Des. 1 & Des.2 \\
\hline I. & DI. Mamak & 100,00 & & & & & & & & \\
\hline 1.1 & Keberhasilan Operasi & & $85,00 \%$ & $90,00 \%$ & $95,00 \%$ & $80,0 \%$ & 85,00 & 90,00 & 95,00 & 80,00 \\
\hline 1.2 & Sisa Tampungan akhir & & 5.768 .284 & 4.564 .916 & 3.784 .299 & 2.980 .162 & 100,00 & 100,00 & 100,00 & 38,41 \\
\hline \multirow[t]{2}{*}{1.3} & Defisit air & & $(6.339 .655)$ & $(5.697 .632)$ & $(1.362 .184)$ & $(8.150 .477)$ & - & 0,00 & 45,5 & 0,00 \\
\hline & & & & & & & 185,00 & 190,00 & 240,51 & 118,41 \\
\hline
\end{tabular}

Sumber: Hasil Perhitungan

Kurva batas bawah untuk alternative pola tanam Desember-I (awal LP di Des-I) direkomendasikan sebagai dasar penyusunan kurva batas bawah, dengan pertimbangan [6] :

- Memiliki prosentase keberhasilan keseimbangan air tertinggi dibanding alternative pola tanam lainnya, yaitu 95\%. Pada kondisi ini diharapkan bahwa pemberian air irigasi DI. Mamak lebih handal.

- Pada akhir operasional keseimbangan air terdapat sisa tampungan akhir $3.784 .299 \mathrm{~m}^{3}$ lebih besar dari target tampungan air waduk sebesar $3.750 .000 \mathrm{~m}^{3}$. Dengan demikian masih tersedia cadangan air untuk kebutuhan penyiapan lahan pada periode berikutnya bilamana inflow ke waduk mengalami keterlambatan. 
- Defisit air waduk pada satu tahun operasional adalah paling sedikit dibanding alternative pola tanam lainnya, dengan demikian pemanfaatan airnya lebih optimal.

\section{Kurva Batas Atas}

Kurva elevasi muka air normal batas atas dianalisis dengan alternatif pola tanam sesuai dengan rekomendasi kurva batas bawah, yaitu Desember I [6]. Karena kurva batas atas ini untuk mempresentasikan kondisi operasional waduk pada tahun basah, maka dipilih debit andalan $20 \%$ dengan total inflow tahunan 81,87 juta $\mathrm{m}^{3}$. Bentuk Kurva untuk pola operasi 2 masa tanam akan disajikan pada Gambar 4.

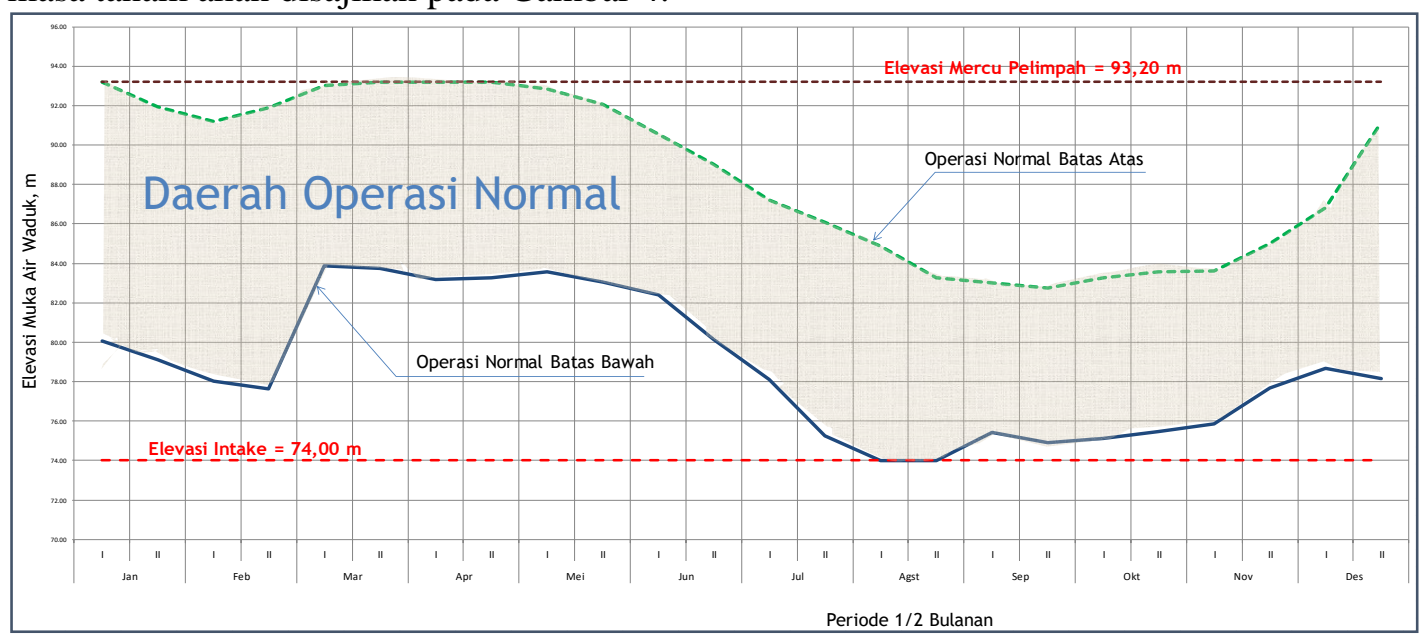

Gambar 4. Kurva Pola Operasi 2 Masa Tanam

Sumber: Hasil Penggambaran

\subsection{Rekomendasi Kurva Pola Operasi dengan 3 Masa Tanam}

Hasil analisis ketersediaan air mengindikasikan bahwa walaupun relatif kecil masih ada potensi inflow Waduk Mamak pada MT-III yang memungkinkan untuk meningkatkan pemanfaatan air waduk menjadi pola tanam 3 musim. Kebutuhan air untuk alternatif pola tanam 3 musim, yaitu : Padi(100\%) - Padi(50\%)/Palawija(50\%) - Palawija (25\%) sedikit lebih besar, yaitu 61,23 juta $\mathrm{m}^{3}$.

Pada tahun kering dimana potensi inflow tahunannya hanya 41,14 juta $\mathrm{m}^{3}$, pemberian air irigasi secara penuh tidak bisa dilakukan sehingga perlu menerapkan $\mathrm{FK}=0,70$ di MT-I dan FK = 0,60 di MT-II [3], sehingga kebutuhan air irigasi tereduksi menjadi sebesar 39,70 juta $\mathrm{m}^{3}$.

Bentuk Kurva Pola Operas Normal Waduk Mamak dengan 3 musim tanam akan disajikan pada Gambar 5. 


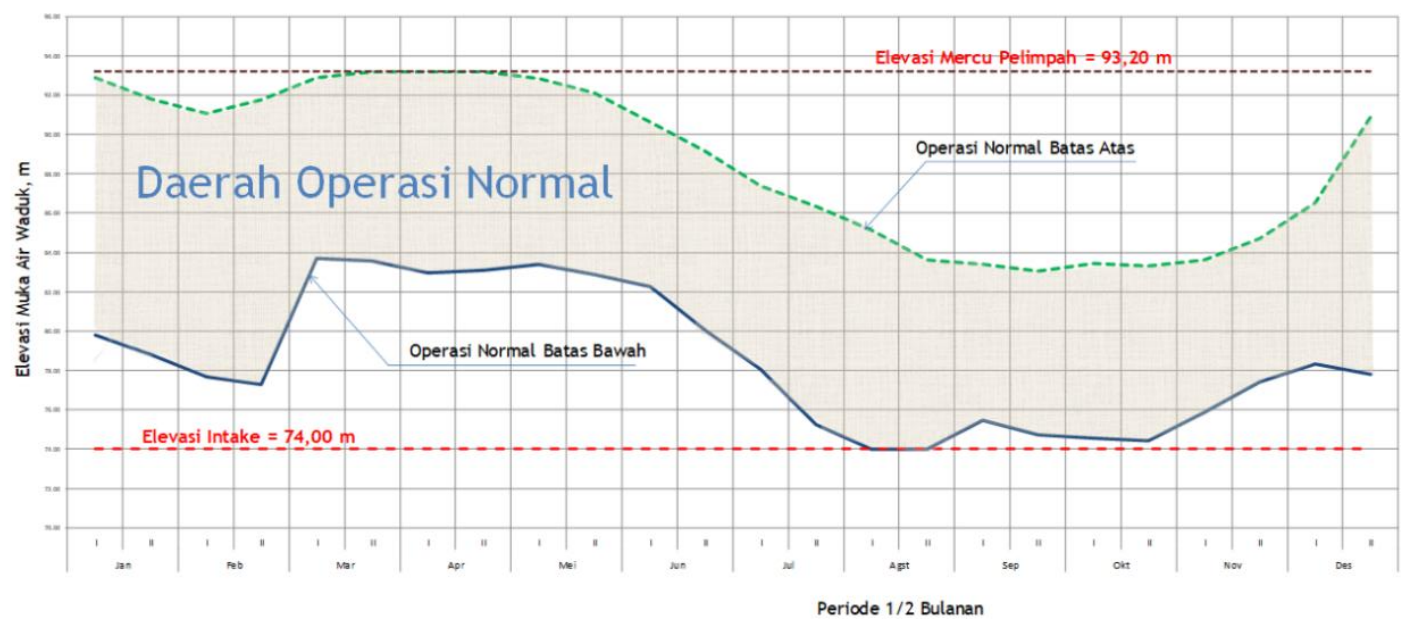

Gambar 5. Kurva Pola Operasi 3 Masa Tanam Sumber: Hasil Penggambaran

\section{Kesimpulan}

Berdasarkan data monitoring inflow ke waduk serta perhitungan dengan Metode Basic Year dapat disimpulkan bahwa potensi inflow waduk Mamak adalah $\pm 81,87$ juta $\mathrm{m}^{3}$ untuk kondisi tahun basah (inflow andalan $20 \%$ ) dan $\pm 41,14$ juta $\mathrm{m}^{3}$ untuk tahun kering (inflow andalan $80 \%$ ). Pola Tanam yang dihitung berdasarkan rencana dari Pemerintah Kabupaten Sumbawa yaitu pola tanam 2 musim dengan 4 alternatif awal masa tanam yaitu, Nop-1, Nop2, Des-1, Des-2 dan dapat kesimpulan bahwa kebutuhan air terendah terjadi ketika MT-I berada pada Des-I dengan angka kebutuhan air sebesar 59.274.127 $\mathrm{m}^{3}$ dengan pola tanam: Padi (100 $\%$ ) - Padi (52\%)/Palawija (48 \%) - Bero. Kebutuhan air yang demikian mengindikasikan bahwa pemberian air akan terpenuhi secara baik pada tahun basah, namun untuk tahun kering perlu menerapkan FK = 0,7 untuk MT-I dan FK = 0,6 untuk MT-II agar angka kebutuhan air dapat tereduksi.

Untuk kondisi pola tanam 3 musim angka kebutuhan air sedikit lebih besar yaitu sebesar 61,23 juta $\mathrm{m}^{3}$ dengan pola tanam: Padi (100\%) - Padi (50 \%)/Palawija (50 \%) - Palawija (25 $\%)$. Kondisi ini dapat terpenuhi seluruhnya pada tahun basah, namun untuk tahun kering perlu menerapkan FK = 0,70 untuk MT-I dan FK = 0,6 untuk MT-II sehingga angka kebutuhan air dapat tereduksi sesuai dengan kondisi potensi inflow [3]. Kondisi keseimbangan air yang optimal dapat dicapai bila MT-I berada pada Des-I dengan pola tanam: Padi (100\%) - Padi (52\%)/Palawija (48 \%) - Bero. Parameter pembandingnya meliputi: keberhasilan pemberian air $95 \%$, defisit air sebesar $1.362 .184 \mathrm{~m}^{3}$, dan tampungan akhir waduk sebesar $3.784 .299 \mathrm{~m}^{3}$. Hasil analisa ini digunakan untuk menetapkan daerah operasi normal waduk dengan kurva yang ditampilkan pada Gambar 4.6. Selanjutnya dalam studi ini juga melakukan rekomendasi terhadap potensi DI. Mamak untuk melakukan pola tanam 3 musim dengan kurva yang ditampilkan pada Gambar 4.7. 


\section{Daftar Pustaka}

[1] Adhi, M. Juwono, P T \& Sholichin, M (2016). Analisa Keruntuhan Bendungan Mamak dan Bendungan Batu Bulan Secara Simultan Pada Sistem Pengaliran Sungai Dedintrik. Malang: Universitas Brawijaya

[2] Anonim (2011). Survey Investigasi Desain Jaringan Irigasi DI. Rababaka dan DI. Tanju Untuk Rababaka Kompleks. Mataram: Mettana Consultant Engineering

[3] Direktoran Jendral Pengaiaran Departemen Pekerjaan Umum (1998). Pedoman Pengalokasian Air. Jakarta: Kementrian Pekerjaan Umum.

[4] Departemen Pekerjaan Umum (2013). Standar Perencanaan Irigasi Kriteria. Perencanaan Bagian Jaringan Irigasi KP-01. Jakarta: Kemetrian Pekerjaan Umum.

[5] Hadryana, A D, Arsana, K, \& Suryantara, G (2015). Analisis Keseimbangan Air/Water Balance Di Das Tukad Sungi Kabupaten Tabanan. Denpasar: Universitas Udayana.

[6] Hatmoko, W (2016). Pengantar Penyusunan Pola Operasi Waduk. Jakarta: Puslitbang Sumber Daya Air.

[7] Jatiwiryono, A (2017). Petunjuk Praktis Penyusunan Pedoman Operasi dan Pemeliharaan Bendungan. Jakarta: Kementrian Pekerjaan Umum.

[8] Kafiansyah, Y. Soetopo, W. Fidari, J. Simulasi Pola Operasi Waduk Pandanduri Dengan Optimasi Faktor K Irigasi. Malang: Universitas Brawijaya.

[9] Montarcih, L (2010). Hidrologi Praktis. Bandung; Lubuk Agung.

[10] Rahman, K I, Harisuseno D, Rispiningtati (2014). Studi Pola Operasi Waduk Selorejo dengan peninggian low water level operasional. Malang: Universitas Brawijaya 